\title{
P01-022 - MEFV gene mutations registered to infevers
}

\author{
A Berdeli, S Nalbantoglu, D Tigli, I Demirel, M Atan \\ From 7th Congress of International Society of Systemic Auto-Inflammatory Diseases (ISSAID) \\ Lausanne, Switerland. 22-26 May 2013
}

\section{Introduction}

Familial Mediterranean Fever (FMF) is the most common hereditary autoinflammatory disorder characterized by fever and abdominal pain. 16p13.3 chromosomally located MEFV gene has been responsible for disease outcome and its protein product, Pyrin, is the key regulator protein of inflammasome complex which leads to IL-1B production and inflammation.

\section{Objectives}

Here, we aimed to identify responsible MEFV gene mutations in clinically prediagnosed FMF patients and link to typical phenotype.

\section{Methods}

Bidirectional DNA Sequencing analysis of MEFV gene in all coding exons and exon-intron boundaries was performed in Turkish patients clinically pre-diagnosed as FMF consulted in Ege University School of Medicine between years 2009-2013 $(\mathrm{n}=8000)$ and in healthy control group individuals $(\mathrm{n}=250)$. For patients who were mutation negative in screened exons, exons 1, 4, 6, 7, 8, and 9 were also analysed.

\section{Results}

14 novel missense and nonsense mutations were investigated and registered to INFEVERS (http://fmf.igh. cnrs.fr/ISSAID/infevers) p.R151S (c.453G>C); p.S154P (c.460T>C); p.S166L(c.497C > T); p.S179N (c.536G>A); p.R241K (c.722G>A), p. P350R(c.1049C>G), p.E456D (c.1368A>C); p.Y471X (c.1413C>A); p.R501C (c.1501C>T); p.S503C (c.1508C>G); p.I506V (c.1516A>G), p.K695N (c.2085G>C); p.L709R (c.2126T>G) and p. I729V (c.2185A>G). In phenotypic correlation, p.Arg241Lys and p.Ser166Leu mutations were linked to recurrent

Molecular Medicine Laboratory, EGE UNIVERSITY, Izmir, Turkey fever; and p.Ile506Val and p.Leu709Arg missense mutations were seen as atypical FMF phenotype while the remaining ones were correlated well with FMF clinical implications.

\section{Conclusion}

Identification of responsible mutations has great importance in disease maintanence, follow-up and proper treatment. It is recommended to prevent overlook uncommon pathogenic mutations in routine techniques via whole gene mutation analysis.

\section{Disclosure of interest}

None declared.

Published: 8 November 2013

doi:10.1186/1546-0096-11-S1-A26

Cite this article as: Berdeli et al:: P01-022 - MEFV gene mutations registered to infevers. Pediatric Rheumatology 2013 11(Suppl 1):A26.

Submit your next manuscript to BioMed Central and take full advantage of:

- Convenient online submission

- Thorough peer review

- No space constraints or color figure charges

- Immediate publication on acceptance

- Inclusion in PubMed, CAS, Scopus and Google Scholar

- Research which is freely available for redistribution
C 2013 Berdeli et al; licensee BioMed Central Ltd. This is an Open Access article distributed under the terms of the Creative Commons Attribution License (http://creativecommons.org/licenses/by/2.0), which permits unrestricted use, distribution, and reproduction in any medium, provided the original work is properly cited. 